\title{
Efficient chiral synthesis by Saccharomyces cerevisiae spore encapsulation of Candida parapsilosis Glu228Ser/(S)-carbonyl reductase II and Bacillus sp. YX-1 glucose dehydrogenase in organic solvents
}

Jingxin Rao ${ }^{1}$, Rongzhen Zhang ${ }^{2,4}$, Hongbo Liang², Xiao-Dong Gao ${ }^{3}$, Hideki Nakanishi ${ }^{3}$ and Yan X 2 $^{*}$

\begin{abstract}
Background: Saccharomyces cerevisiae AN120 osw2 $\Delta$ spores were used as a host with good resistance to unfavorable environment. This work was undertaken to develop a new yeast spore-encapsulation of Candida parapsilosis Glu228Ser/(S)-carbonyl reductase II and Bacillus sp. YX-1 glucose dehydrogenase for efficient chiral synthesis in organic solvents.

Results: The spore microencapsulation of E228S/SCR II and GDH in S. cerevisiae AN120 osw2 $\triangle$ catalyzed (R)-phenylethanol in a good yield with an excellent enantioselectivity (up to 99\%) within $4 \mathrm{~h}$. It presented good resistance and catalytic functions under extreme temperature and $\mathrm{pH}$ conditions. The encapsulation produced several chiral products with over $70 \%$ yield and over $99 \%$ enantioselectivity in ethyl acetate after being recycled for 4-6 times. It increased substrate concentration over threefold and reduced the reaction time two to threefolds compared to the recombinant Escherichia coli containing E228S and glucose dehydrogenase.
\end{abstract}

Conclusions: This work first described sustainable enantioselective synthesis without exogenous cofactors in organic solvents using yeast spore-microencapsulation of coupled alcohol dehydrogenases.

Keywords: (S)-carbonyl reductase II, Glucose dehydrogenase, Sustainable enantioselective catalysis, Organic solvent, Spore-microencapsulation

\section{Background}

Alcohol dehydrogenases (ADHs) in organic synthesis have attracted particular interest for the improvement of substrate permeability, cofactor regeneration and process simplification [1, 2]. However, few ADH exhibited solvent-resistant properties associated with their sustainable enantioselective catalytic functions [3]. Enzyme encapsulation is a practical technique to improve enzyme stability and performance, such as the

\footnotetext{
*Correspondence: yxu@jiangnan.edu.cn

${ }^{2}$ Key Laboratory of Industrial Biotechnology of Ministry of Education \& School of Biotechnology, Jiangnan University, Wuxi 214122, People's Republic of China

Full list of author information is available at the end of the article
}

improvement of substrate transportation and product extraction efficiency in organic solvent $[4,5]$.

To realize efficient enantioselective synthesis, chiral-forming $\mathrm{ADH}$ and cofactor-recycling $\mathrm{ADH}$ are encapsulated for in situ cofactor regeneration $[6,7]$. Because of the complexity and variety of ADHs, coencapsulation of multiple ADHs in one cage often leads to rapid denaturation and/or sharply decreased activity. Liu et al. encapsulated glutamate dehydrogenase and lactate dehydrogenase and their cofactor in three nanoparticles, but they performed reaction with low concentrated substrates [8]. El-Zahab et al. carried out stereospecific reaction with $10 \mathrm{mM}$ glutamate with particle-tethered NADH shuttled between co-immobilized 
oxidoreductases on nanoporous silica glass $[9,10]$. These unsatisfied efficient reactions suffer from low electron transfer efficiencies because of the separate immobilization of ADHs, exposure of the enzymes to toxic substrates, and the limited enzyme conformational transitions [11-13]. Therefore, it is a long-standing challenge in co-encapsulation of ADHs to enhance enzyme stability and reusability for efficient stereoselective synthesis [14].

Saccharomyces cerevisiae spore is reported with good resistance to extreme conditions. In absence of nitrogen and the presence of a nonfermentable carbon source, $S$. cerevisiae cells cease vegetative growth and turn to be spores [15]. Yeast spore walls contain dityrosine and chitosan layers, which can encapsulated proteins and protect encapsulated proteins from various environmental stresses, such as digestive enzymes, heat and organic solvents $[16,17]$. We recently deleted osw $2 \Delta$ gene in $S$. cerevisiae AN120 spores, whose dityrosine and chitosan layers are structurally loose with better permeability to substrates $[18,19]$. The entrapped enzymes in S. cerevisiae AN120 osw $2 \Delta$ spores showed a higher activity than in the vegetative cells [18].

Previously, we reported a mutant of Candida parapsilosis (S)-carbonyl reductase II (SCR II, EC 1.1.1.148), in which glutamate-228 was replaced with serine (E228S/ SCRII). E228S/SCRII and glucose dehydrogenase (GDH, EC 1.1.1.47) from Bacillus sp. YX-1 were coexpressed in Escherichia coli. The enzyme-coupled system catalyzed acetophenone (AP) to $(R)$-phenylethanol $((R)-\mathrm{PE})$ with an optical purity of $99.5 \%$ and a yield of $92.2 \%$ within $12 \mathrm{~h}$ [3]. It is necessary to improve yield and shorten the reaction duration obtained with $E$. coli. The improvement of substrate solubility and activity under organic solvents are more important for efficient reaction.

In this work, we coencapsulate E228S/SCR II and GDH in S. cerevisiae AN120 osw $2 \Delta$. The encapsulated enzymes were entrapped in loose-walled S. cerevisiae AN120 osw $2 \Delta$ spores, and the substrates and cofactor passed through the yeast spore smoothly. The spore microencapsulation could catalyze highly concentrated substrate in organic solvents, and exhibited excellent catalytic efficiency with long-term and good recycling stabilities. This work performed efficient enantioselective synthesis in organic solvents using spore-microencapulation containing chiral-forming $\mathrm{ADH}$ and cofactor-recycling $\mathrm{ADH}$.

\section{Results}

\section{Co-encapsulation of E228S/SCRII and GDH in spores of $S$.} cerevisiae AN120 osw2A

It was reported that the Shine-Dalgarno (SD) and aligned spacing (AS) sequence could initiate protein translation efficiently [20]. The coupled system E228S-SD-AS-G was constructed using $\mathrm{SD}$ and $\mathrm{AS}$ sequence as a linker between E228S/SCRII and GDH [3]. A monomeric green fluorescent protein (GFP) was fused at $\mathrm{N}$-terminal of E228S-SD-AS-G to construct GFP-E228S-SD-AS-G. The co-encapsulation of E228S/SCRII and GDH in S. cerevisiae AN120 osw2 $\Delta$ was performed by SD-Trp screening as described in "Materials and methods" [18]. The protein expression of E228S/SCRII and GDH was confirmed by laser scanning confocal microscope [21]. The green fluorescence distribution in $S$. cerevisiae osw $2 \Delta /$ GFP-E228S-SD-AS-G cells under laser scanning confocal microscope indicated that most of E228S-SD-AS-G proteins were entrapped in yeast-spore wall or on membrane surface (Fig. 1).

The protein expression of E228S/SCRII and GDH was further confirmed by western blotting. A band of $30 \mathrm{kDa}$ was detected in S. cerevisiae osw $2 \Delta / \mathrm{E} 228 \mathrm{~S}$ spores, which was consistent with molecular mass of E228S. Two bands of $30 \mathrm{kDa}$ and $28 \mathrm{kDa}$ in accordance with E228S and E228S-SD-AS-G were observed in S. cerevisiae osw2 $\Delta /$ E228S-SD-AS-G spores. Since GFP was coexpressed with E228S-SD-AS-G, there were two bands of $57 \mathrm{kDa}$ and $28 \mathrm{kDa}$ (Fig. 2), in accordance with the theoretical molecular mass of GFP-E228S and GDH in S. cerevisiae osw $2 \Delta /$ GFP-E228S-SD-AS-G spores. Those results further suggested E228S/SCRII or/and GDH were expressed and retained inside $S$. cerevisiae AN120 osw $2 \Delta$ spores.

The recombinant S. cerevisiae osw $2 \Delta / \mathrm{E} 228 \mathrm{~S}$, S. cerevisiae osw2 $2 / \mathrm{E} 228 \mathrm{~S}$ spore, S. cerevisiae osw2 $2 / \mathrm{E} 228 \mathrm{~S}$ SD-AS-G and S. cerevisiae osw2 $\Delta /$ E228S-SD-AS-G was dealed with $\beta$-glucanase and lyzed by high pressures to obtain their cell-free extracts according to "Materials and methods". They showed the specific activity of 46.7, 47.5, 30.5 and $31.1 \mathrm{U} \mathrm{mg}^{-1}$ in their cell-free extracts, respectively. By kinetic analysis, the spore-encapsulation S. cerevisiae osw2 $2 / \mathrm{E} 228 \mathrm{~S}-\mathrm{SD}-\mathrm{AS}-\mathrm{G}$ showed the higher $k_{\text {cat }}$ value $\left(18.9 \mathrm{~S}^{-1}\right)$ than the free enzyme E228S-SD-AS-G $\left(15.6 \mathrm{~S}^{-1}\right)$, but maintaining a $k_{\text {cat }}$ value $(3.2 \mu \mathrm{M})$ essentially the same with respect to the free enzyme.

\section{Efficient and sustainable ( $R$ )-PE synthesis by spore microencapsulation in aqueous phase}

The free enzyme E228S/SCRII (Free ${ }_{\mathrm{E} 228 \mathrm{~S}}$ ), free coupled enzymes containing E228S/SCRII and GDH $\left(\right.$ Free $\left._{\mathrm{E} 228 \mathrm{~S}-\mathrm{GDH}}\right), \quad S$. cerevisiae osw2 $\Delta / \mathrm{E} 228 \mathrm{~S}$ spore $\left(\right.$ Spore $\left._{\mathrm{E} 228 \mathrm{~S}}\right)$, and $S$. cerevisiae osw2 $/ \mathrm{E} 228 \mathrm{~S}-\mathrm{SD}-\mathrm{AS}$ $\mathrm{G}$ spore (Spore E228S-GDH $_{\text {) were }}$ used to catalyze $8 \mathrm{~g}$ $\mathrm{L}^{-1}(\approx 67 \mathrm{mM})$ AP to $(R)$-PE in PBS buffer. Free ${ }_{\mathrm{E} 228 \mathrm{~S}}$, Free $_{\mathrm{E} 228 \mathrm{~S}-\mathrm{GDH}}$, Spore $_{\mathrm{E} 228 \mathrm{~S}}$ and Spore $_{\mathrm{E} 228 \mathrm{~S}-\mathrm{GDH}}$ retained $89-95 \%$ of yields and over $99 \%$ of enantiomeric excess $(e e)$ in $(R)-\mathrm{PE}$ production (Table 1). Spore $\mathrm{E}_{\mathrm{E} 228 \mathrm{~S}}$ and Spore $_{\text {E228S-GDH }}$ gave the same enantiopurity and slightly 


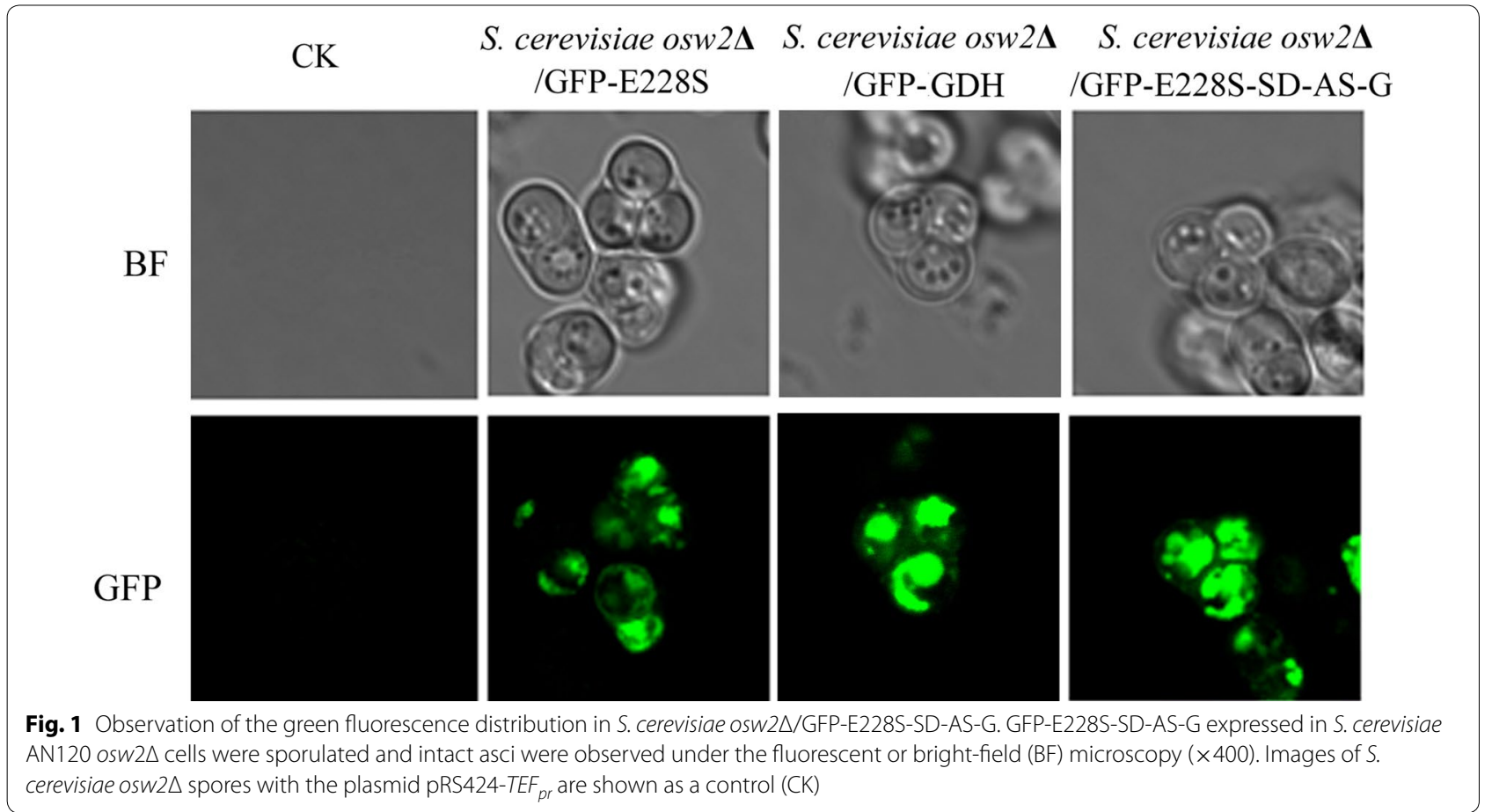

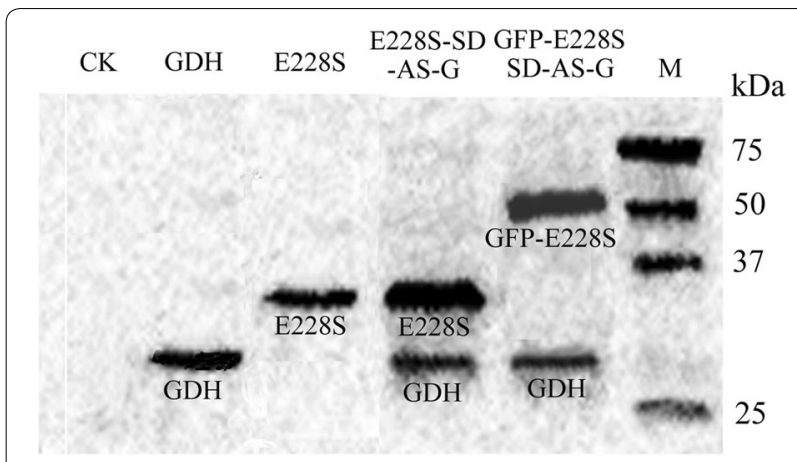

Fig. 2 Western blotting analysis of the lysates of the recombinant S. cerevisiae osw2 $\triangle$ spores. The spore with pRS424-TEF pr plasmid was used as control

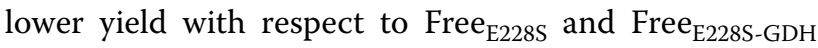
(Table 1). The spore microencapsulation accomplished the enantioselective synthesis of $(R)$-PE much more quickly than Free $_{\mathrm{E} 228 \mathrm{~S}}$ and Free $_{\mathrm{E} 228 \mathrm{~S}-\mathrm{GDH}}$ in aqueous phase. The Spore ${ }_{\mathrm{E} 228 \mathrm{~S}}$ and Spore $\mathrm{E}_{\mathrm{E} 228 \mathrm{~S}-\mathrm{GDH}}$ (with GDH enzyme for cofactor regeneration) gave $83 \%$ and $86 \%$ in yields, and over $99 \%$ retention in optical purity of $(R)-\mathrm{PE}$ even if they were reused 10 times for asymmetric biosynthesis (Table 1).

\section{Spore microencapsulation presents good resistance to extreme conditions}

The Spore ${ }_{\mathrm{E} 228 \mathrm{~S}-\mathrm{GDH}}$ displays similar optimal conditions: $35^{\circ} \mathrm{C}$ and $\mathrm{pH} 6.5$ for enantioselective synthesis of $(R)-\mathrm{PE}$.
The stability of Spore ${ }_{\mathrm{E} 228 \mathrm{~S}-\mathrm{GDH}}$ for asymmetric synthesis of $67 \mathrm{mM}$ AP to $(R)$-PE was investigated under extreme temperature and $\mathrm{pH}$, repetitive freezing-thawing and air-drying conditions. When the Spore ${ }_{\mathrm{E} 228 \mathrm{~S}-\mathrm{GDH}}$ was kept at $20-50{ }^{\circ} \mathrm{C}$ for $1 \mathrm{~h}$, it produced $(R)$-PE with $75-93 \%$ yield (Fig. 3). It catalyzed the stereoselective synthesis of $(R)$ $\mathrm{PE}$ with about $68 \%$ yield when the Spore $_{\text {E228S-GDH }}$ was incubated at $50{ }^{\circ} \mathrm{C}$ for $1 \mathrm{~h}$. When kept at $\mathrm{pH} 5.0-9.0$ for $5 \mathrm{~h}$, the Spore $_{\mathrm{E} 228 \mathrm{~S}-\mathrm{GDH}}$ produced $(R)$-PE with over $75 \%$ yield. Even at extreme pH 4.0 and 10.0 for $5 \mathrm{~h}$, it produced $(R)$-PE in yields of over $65 \%$. In all above cases, the Spore $_{\text {E228S-GDH }}$ retained excellent optical purity over $99 \%$.

In repetitive freezing-thawing cycles, virtually no less in optical purity and over $84 \%$ yield of $(R)$-PE was detected after 20 weeks (Fig. 4). When the Spore ${ }_{\text {E228S-GDH }}$ was air-dried at $16{ }^{\circ} \mathrm{C}$ for $12 \mathrm{~h}$ and $24 \mathrm{~h}$, it exhibited good yield (82\% and 66\%) for stereoselective synthesis of $(R)$ PE in PBS solution. When the Spore E228S-GDH $_{\text {was incu- }}$ bated at $30^{\circ} \mathrm{C}$ in air-drying conditions for $12 \mathrm{~h}$ and $24 \mathrm{~h}$, it produced $(R)$-PE with $69 \%$ and $45 \%$ yields. In all cases (R)-PE was synthesized with over $98 \%$ enantioselectivity (Fig. 5).

\section{Sustainable enantioselective synthesis of $(R)$-PE by spore microencapsulation in organic solvents}

The enantioselective synthesis of $25 \mathrm{~g} \mathrm{~L}^{-1}(\approx 208 \mathrm{mM})$ AP to $(R)-\mathrm{PE}$ was carried out by the Spore E228S-GDH $_{\text {in sol- }}$ vent solutions (PBS buffer solution/solvent $(170: 30 \mathrm{v} / \mathrm{v})$ ). The Spore $_{\text {E228S-GDH }}$ produces $(R)$-PE in moderate to good 
Table 1 Enantioselective synthesis of $(R)$-PE by yeast-spore coencapsulation of ADHs and free enzymes in aqueous medium

\begin{tabular}{|c|c|c|c|c|c|}
\hline & Samples & Yield (\%) ${ }^{a}$ & $e e(\%)^{b}$ & $\begin{array}{l}\text { Reduction durations } \\
(\mathrm{h})^{\mathrm{c}}\end{array}$ & $\begin{array}{l}\text { Productivity } \\
\left(\mathrm{mM} \mathrm{h}^{-1} \mathrm{~g}^{-1}\right)\end{array}$ \\
\hline \multirow[t]{3}{*}{ E228S SCRII } & Free & 93 & $>99$ & 8 & 77.9 \\
\hline & Encapsulated $^{\mathrm{d}}$ & 89 & $>99$ & 6 & 99.4 \\
\hline & Encapsulated (10) & 83 & $>99$ & 60 & 92.7 \\
\hline \multirow[t]{3}{*}{ E228S-GDH } & Free & 95 & $>99$ & 6 & 106.1 \\
\hline & Co-encapsulated & 93 & $>99$ & 2 & 311.6 \\
\hline & Co-encapsulated (10) & 86 & $>99$ & 20 & 288.1 \\
\hline
\end{tabular}

All reactions were carried out at $30^{\circ} \mathrm{C}$ in $100 \mathrm{mM}$ PBS buffer solution (pH 7.4) by using free ADHs (0.1 mg) and Spore $\mathrm{E} 228 \mathrm{~S}_{\text {or Spore }} \mathrm{E} 228 \mathrm{~S}-\mathrm{GDH}(0.1 \mathrm{~g})$. The concentration of $\mathrm{AP}$ was $8 \mathrm{~g} / \mathrm{L}(\approx 67 \mathrm{mM})$

a $\%$ yield of $(R)-P E$ was determined by HPLC

b ee: enantiomeric excess, the ee values of $(R)$-PE were determined using a chiral stationary phase on a Chiralcel OB-H column [3]

c Reaction duration was determined when the product $(R)$-PE was produced with the highest yield

${ }^{d}$ The value in parentheses denotes the times the encapsulated enzymes was recycled for reactions

yield (51-88\%) in solvent solutions (Table 2). When the Spore $_{\text {E228S-GDH }}$ were reused for asymmetric reduction in ethyl acetate solution for 6 times, it gave $72 \%$ yield and perfect enantioselectivity $(>99 \% e e)$. The Spore $_{\text {E228S-GDH }}$ was reused for (R)-PE production for 3-5 times in DMSO, 2-propanol, hexane and urea, it gave over $70 \%$ yield and high enantioselectivity (>93\% ee) (Table 2). These results indicate that the encapsulation of ADHs in yeast spores is not inactivated by polar solvents, but keep good performance for asymmetric synthesis of AP to $(R)$ $\mathrm{PE}$. Although the Spore $\mathrm{E}_{\mathrm{E} 228 \mathrm{~S}-\mathrm{GDH}}$ catalyzed $(R)-\mathrm{PE}$ with a higher yield in the aqueous medium, the use of organic solvent makes the process more efficient by allowing high concentration of substrates $\left(25 \mathrm{~g} \mathrm{~L}^{-1} \approx 208 \mathrm{mM}\right)$ to be used, and the same yeast-encapsulation can be reused at least six times for sustainable reductions in ethyl acetate (Fig. 6). The use of ethyl acetate makes the Spore E228S-GDH catalyze the enantioselective reaction accessible to hydrophobic substrates. Since the reaction was performed in $15 \%$ ethyl acetate and chiral product was extracted with twofold volume of ethyl acetate, more ethyl acetate was added directly to the reaction mixture and simplified the product extraction process after reaction finished.

\section{Enantioselective synthesis of chiral products in ethyl acetate}

A serial of phenyl-ring-containing ketones were stereoselectively catalyzed using glucose as a co-substrate

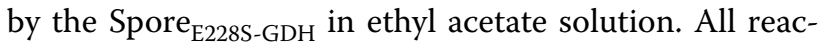
tions were performed with $200 \mathrm{mM}$ substrate. The Spore $_{\text {E228S-GDH }}$ catalyzed the enantioselective reaction of $\mathrm{AP}(\mathbf{1 a})$ and $4^{\prime}$-methoxyacetophenone (3a) to $(R)-\mathrm{PE}((R)$ 1b) and $(R)$-1-(4-methoxyphenyl ethanol $((R)-3 \mathbf{b})$ with slightly lower yield in ethyl acetate than free enzyme did in aqueous medium (Table 3). 4'-Methylacetophenone (2a), 4'-bromoacetophenone (4a) and 4'-chloroacetophenone (5a) were catalyzed to their corresponding chiral alcohols $((R)-\mathbf{2 b},(R)-\mathbf{4 b}$ and $(R)-\mathbf{5 b})$ with high yields (79-85\%) and excellent enantioselectivity (>99\% ee) by

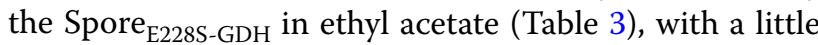
lower yield in ethyl acetate but the similar enantioselectivity when compared with the same resulting products by the free enzyme in PBS buffer (Table 3). 2-Chloroacetophenone (6a) and 3-chloroacetophenone (7a) were catalyzed to $(R)-1-(2$-chlorophenyl) ethanol $((R)-6 \mathbf{b})$ and $(R)$-1-(3-chlorophenyl) ethanol $((R)-7 \mathbf{b})$ with almost the same yields by using Spore ${ }_{\mathrm{E} 228 \mathrm{~S}-\mathrm{GDH}}$ in ethyl acetate comparable with free enzymes in aqueous medium (Table 3).

Although the linear chain ketones, such as 2-hexanone (9a), 2-pentanone (10a), 2-heptanone (11a) and 2-octanone (12a) were catalyzed to $(R)$-2-hexanol $((R)$ 9b), (R)-2-pentanol $((R)$-10b), $(R)$-2-heptanol $((R)$-11b) and $(R)$-2-octanol $((R)$-12b) with moderate enantioselectivity $(65-86 \% e e)$ and a rather low yield (19-34\%) by using free enzyme in aqueous medium, significantly improved yields (43-60\%) and optical purity (85-94\%) were obtained by using the Spore E228S-GDH $_{\text {in ethyl ace- }}$ tate (Table 3). The enantioselective reaction of sterically demanding keto esters was chosen for asymmetric

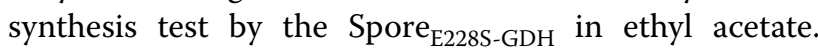
Methyl acetoacetate (13a), ethyl benzoylacetate (14a) and ethyl 4,4,4-trichloroacetoacetate (15a) were transformed to (R)-methyl-3-hydroxybutyrate $((R)-\mathbf{1 3 b})$, $(R)$-ethyl-3-hydroxy-3-phenylpropionate $((R)-\mathbf{1 4 b})$ and $(R)$-ethyl-3-hydroxy-4,4,4-trichlorobutyrate $\quad((R)-\mathbf{1 5 b})$ with moderate enantioselectivity $(77-83 \%)$ and rather low yields (26-40\%) using free enzymes in PBS solution. Interestingly, the yields of $(R)-\mathbf{1 3 b},(R)-\mathbf{1 4} \mathbf{b}$ and $(R)-\mathbf{1 5 b}$ 

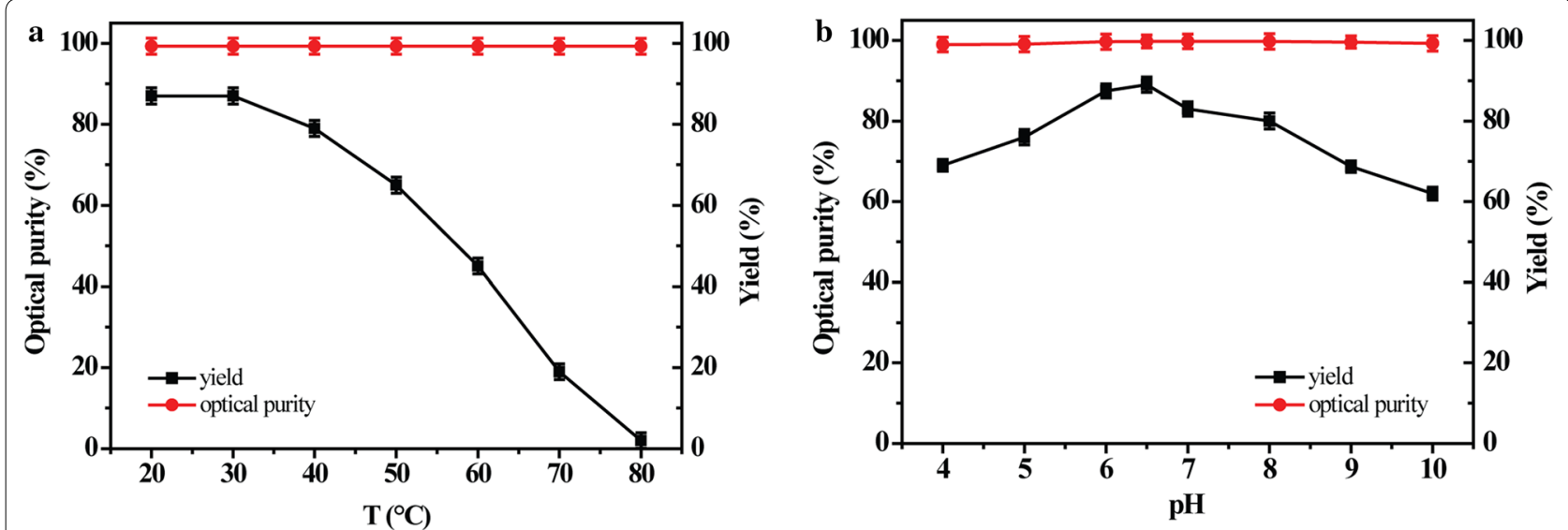

Fig. 3 The temperature $(\mathbf{a})$ and $\mathrm{pH}$ (b) dependence of Spore $\mathrm{E} 2285-\mathrm{GDH}_{\mathrm{H}}$ for asymmetric synthesis of (R)-PE. The Spore $\mathrm{E}_{\mathrm{E} 228 \mathrm{~S}-\mathrm{GDH}}$ was incubated in a

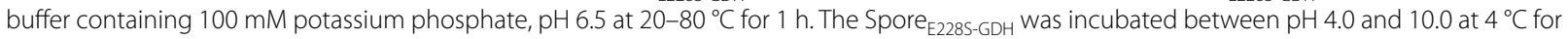
$5 \mathrm{~h}$

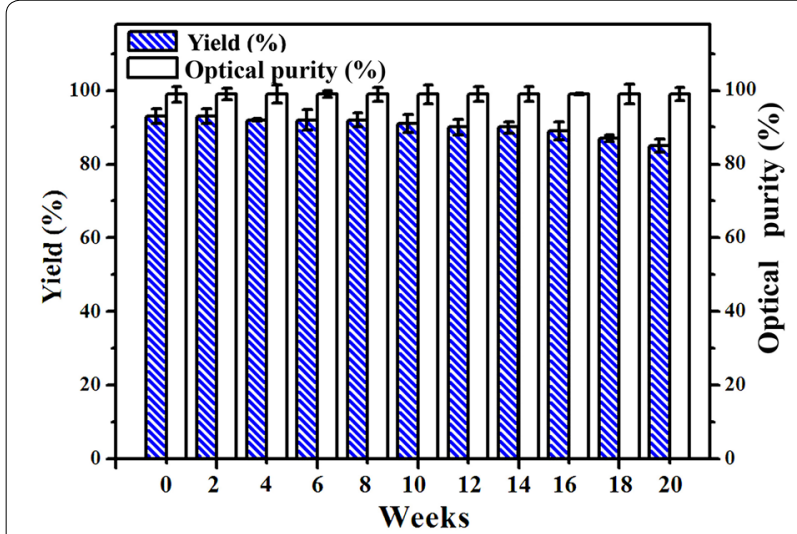

Fig. 4 Asymmetric synthesis of (R)-PE by Spore ${ }_{E 228 S-G D H}$ in freezing

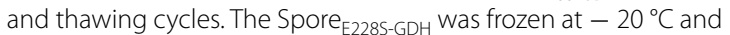
was thawed at room temperature. The freezing-thawing process was repeated at least once a day. Some of Spore ${ }_{\text {E228S-GDH }}$ was used for enantiospecific reaction, and the rest was taken back at $-20^{\circ} \mathrm{C}$

were significantly increased and their ee values were improved to $90-97 \%$ by using the Spore ${ }_{\mathrm{E} 228 \mathrm{~S}-\mathrm{GDH}}$ in ethyl acetate (Table 3).

\section{Discussion}

We previously constructed a coupled system E228S-SDAS-G using a Shine-Dalgarno (SD) and aligned spacing (AS) sequence as a linker between E228S/SCRII and GDH [3]. In this work, we coexpressed E228S/SCRII and GDH in S. cerevisiae AN120 osw2 2 . With potassium acetate as the only carbon, $S$. cerevisiae cells cease vegetative growth and turn to be spores [15], so the two enzymes: E228S/SCRII and GDH were encapsulated in the yeast spores. The spore encapsulation was confirmed by laser scanning confocal microscope. Gerke et al. reported many genes involved in aerobic respiration, an essential pathway for sporulation, so the sporulation efficiency varied in diverse yeast strains [22]. When the cells was cultured in $2 \%$ potassium acetate medium for $24 \mathrm{~h}$, the ratio between spores and cells was over $9: 1$ by microscopic examination, the spores were harvested and lyzed by high pressures and the active yeast-spores encapsulated E228S/SCRII and E228S-SD-AS-G, named Spore $_{\text {E228S-GDH }}$ were obtained for further experiments.

The yeast cells and its corresponding spore exhibited almost the same catalytic activity. The $S$. cerevisiae osw $2 \Delta / \mathrm{E} 228 \mathrm{~S}$ exhibit higher activity than E228S in the coupled system. Suda et al. showed that the outermost dityrosine layer works as a diffusion barrier for soluble proteins [16]. Since osw $2 \Delta$ gene in S. cerevisiae AN120 spores was deleted, whose dityrosine and chitosan layers are structurally loose, making substrate enter into or out of the cells more easily. So the entrapped enzymes in S. cerevisiae AN120 osw $2 \Delta$ spores did not decreased the enzyme activity [18]. The spore encapsulation resulted in the higher catalytic efficiency $\left(5.87 \times 10^{6} \mathrm{~S}^{-1} \mathrm{M}^{-1}\right)$ than the free enzyme. The reaction catalyzed by the SCRs is a sequential type, with the coenzymes binding to the free form of the enzyme and subsequently to the substrates according to the kinetics of the interaction [23]. The change in $k_{\text {cat }}$ value may be due to the faster cofactor transfer in the reaction system by spore-encapsulation.

Enantiopure aryl alcohols serve as valuable intermediates for preparation of antidepressants, anti-asthmatics, cholesterol-lowering agents, adrenergic receptor agonists, and NK1 antagonists, etc. [24, 25]. For example, $(R)-\mathrm{PE}$ is a very useful chiral block in the fine chemical and pharmaceutical industry $[26,27]$. The Spore E228S-GDH $_{2}$ 

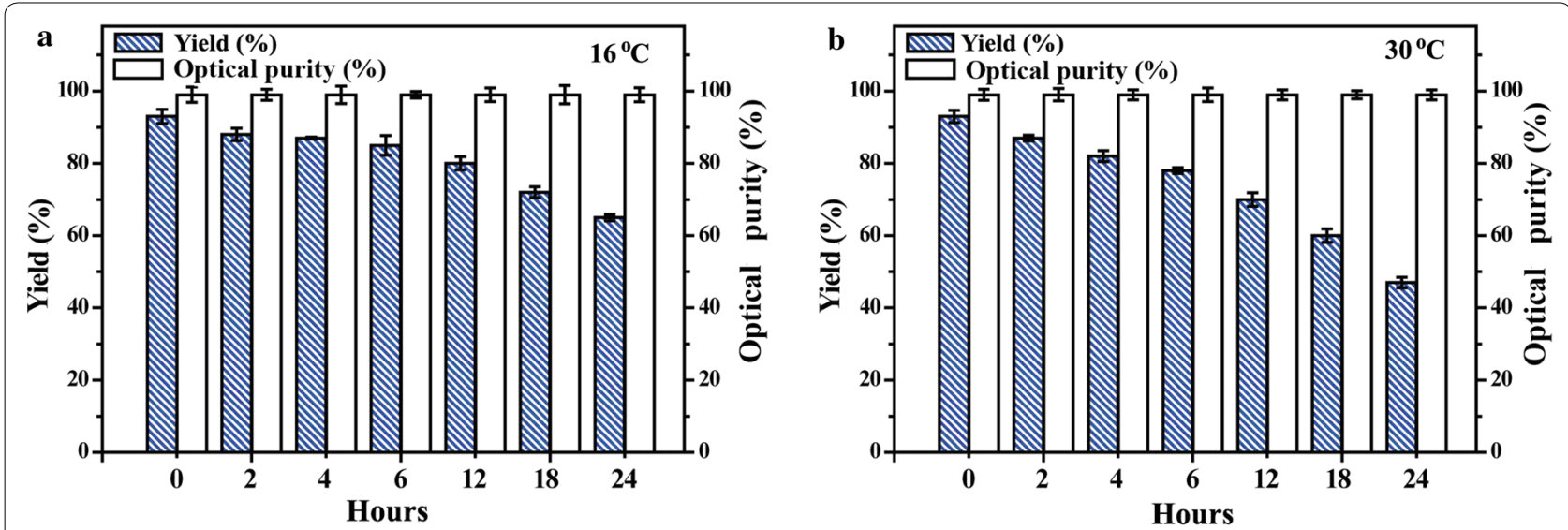

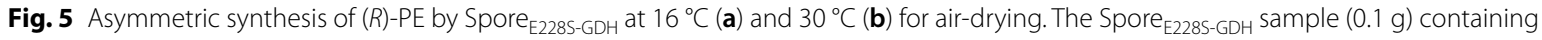
encapsulated E228S/SCRII-GDH was stored at $16^{\circ} \mathrm{C}$ or $30^{\circ} \mathrm{C}$ for air-drying. The samples were taken for asymmetric synthesis of $(R)-P E$ each $2-6 \mathrm{~h}$

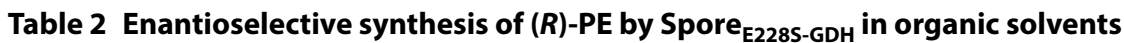

\begin{tabular}{|c|c|c|c|c|c|}
\hline Solvent & $\log P$ & Yield (\%) $)^{a}$ & $e e(\%)$ & Reduction durations & $\begin{array}{l}\text { Productivity } \\
\left(\mathrm{mM} \mathrm{h}^{-1} \mathrm{~g}^{-1}\right)\end{array}$ \\
\hline PBS & & $93(95)$ & $>99(>99)$ & $4.5 \mathrm{~h}$ & $429.9(439.1)$ \\
\hline Ethyl acetate & 0.68 & $88(43)$ & $>99(70)$ & $4.5 \mathrm{~h}(10 \mathrm{~h})$ & $406.8(89.4)$ \\
\hline Ethyl acetate (6) ${ }^{\mathrm{b}}$ & 0.68 & 72 & $>99$ & $27 \mathrm{~h}$ & 554.7 \\
\hline DMSO & -1.3 & $81(46)$ & $>99(85)$ & $4 \mathrm{~h}(10 \mathrm{~h})$ & $421.2(95.7)$ \\
\hline DMSO (3) & -1.3 & 70 & $>99$ & $12 \mathrm{~h}$ & 121.3 \\
\hline 2-Propanol & 0.33 & 85 & 98 & $5 \mathrm{~h}$ & 353.6 \\
\hline 2-Propanol (5) & 0.33 & 70 & 95 & $25 \mathrm{~h}$ & 291.2 \\
\hline Tert-butanol & 0.6 & $72(41)$ & $96(82)$ & $5 \mathrm{~h}(12 \mathrm{~h})$ & $299.5(71.1)$ \\
\hline Methylbenzene & 2.5 & 70 & 98 & $5 \mathrm{~h}$ & 291.2 \\
\hline Cyclohexane & 3.2 & $51(39)$ & $98(92)$ & $5 \mathrm{~h}(12 \mathrm{~h})$ & $212.2(67.6)$ \\
\hline Nonane & 2.9 & 72 & 96 & $5 \mathrm{~h}$ & 299.5 \\
\hline Hexane & 3.5 & 80 & 98 & $4.5 \mathrm{~h}$ & 369.8 \\
\hline Hexane (3) & 3.5 & 70 & 93 & $13.5 \mathrm{~h}$ & 107.9 \\
\hline Ethyl isovalerate & 2.3 & 68 & 96 & $4.5 \mathrm{~h}$ & 314.3 \\
\hline Urea & -2.1 & 82 & 97 & $4.5 \mathrm{~h}$ & 379.0 \\
\hline Urea (4) & -2.1 & 70 & 93 & $18 \mathrm{~h}$ & 80.9 \\
\hline
\end{tabular}

Unless otherwise stated, all reactions were performed at $30^{\circ} \mathrm{C}$ in $100 \mathrm{mM} \mathrm{PBS}$ buffer solution ( $\left.\mathrm{pH} 7.4\right)$ by using $0.1 \mathrm{~g} \mathrm{Spore} \mathrm{E}_{228 \mathrm{~S}-\mathrm{GDH}} \cdot \mathrm{The}$ reaction solution $(2 \mathrm{~mL})$ consists of $1.7 \mathrm{~mL} 100 \mathrm{mM}$ PBS buffer ( $\mathrm{pH} 7.4)$ and $0.3 \mathrm{~mL}$ solvents. AP concentration was $25 \mathrm{~g} / \mathrm{L}(\approx 208 \mathrm{mM})$

a $(R)$-PE synthesis results with free enzymes in $200 \mathrm{~mL}$ PBS buffer $(100 \mathrm{mM}, \mathrm{pH} 7.4)$ are given in parentheses. AP concentration was $8 \mathrm{~g} / \mathrm{L}(\approx 67 \mathrm{mM})$

b The values in parentheses in this column denote the recycled times for enantioselective synthesis

catalyzes the biosynthesis of AP to (R)-PE within $2 \mathrm{~h}$, threefold shorter compared to Free $\mathrm{E} 228 \mathrm{~S}-\mathrm{GDH}$. The recombinant $(S)$-carbonyl reductase in S. cerevisiae produced chiral products with an optical purity of $92.3 \%$ and a yield of $81.8 \%$ in $24 \mathrm{~h} \mathrm{[28].} \mathrm{The} \mathrm{recombinant} \mathrm{E.} \mathrm{coli} \mathrm{harboring}$ SCRII and GDH performed enantioselective reaction within $12 \mathrm{~h}$ [3]. The significantly decreased reaction time by Spore ${ }_{\mathrm{E} 228 \mathrm{~S}-\mathrm{GDH}}$ than Free ${ }_{\mathrm{E} 228 \mathrm{~S}-\mathrm{GDH}}$ can be partly attributed to the three reasons: the free transportation of substrate and cofactor into and out of S. cerevisiae AN120 osw $2 \Delta$ spores [18]; the "pure" conditions in the yeast spores, where few other enzymes, i.e., proteases does not bother the enantioselective reactions [16, 19]; and the assembly of ADH enzymes into cell-molecular architectures (yeast spores) enhancing the catalytic efficiency and/or preventing loss of toxic intermediates that hinder cellular functions [18, 29, 30]. Higher enantioselective efficiency by the Spore E228S-GDH $_{\text {than Spore }}$ E228S $_{\text {is due to }}$ the introduction of GDH for in situ cofactor regeneration in Spore ${ }_{\mathrm{E} 228 \mathrm{~S}-\mathrm{GDH}}$ [31]. This is consistent with the study 


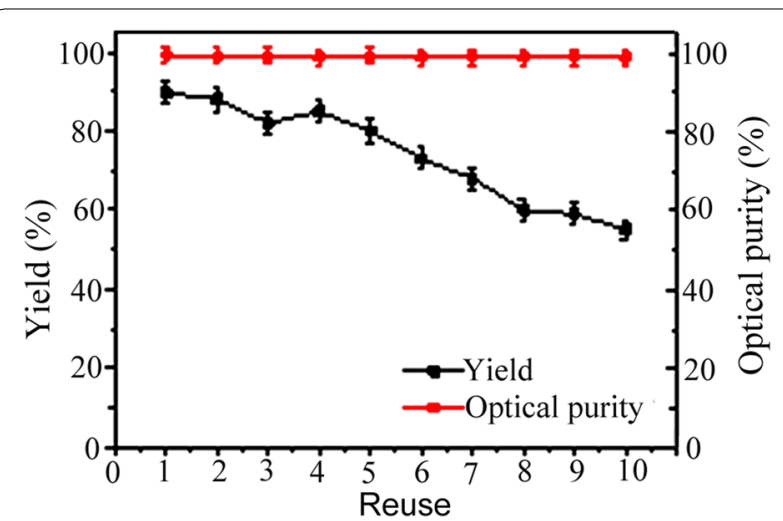

Fig. 6 The reusability of spore-microencapsulation Spore E228S-GDH $_{\text {for }}$ asymmetric synthesis of (R)-PE in ethyl acetate

of ADHs-catalyzed reactions by Gröger et al., who developed a highly efficient "designer cells" for the desired asymmetric reaction by coexpressing the corresponding alcohol dehydrogenase with GDH enzyme [32].

The Spore $_{\text {E228S }}$ and Spore $_{\text {E228S-GDH }}$ could be recycled for stereoselective reaction, while the Free $_{\mathrm{E} 228 \mathrm{~S}}$ and Free $_{\text {E228S-GDH }}$ could not be reused since ethyl acetate (required for the product ( $R$ )-PE extraction) denatured them. The Spore $_{\mathrm{E} 228 \mathrm{~S}}$ and Spore $\mathrm{E}_{\mathrm{E} 228 \mathrm{~S}-\mathrm{GDH}}$ gave $83 \%$ and $86 \%$ in yields, and over $99 \%$ retention in optical purity of $(R)$-PE even if they were reused 10 times for asymmetric biosynthesis. It was very necessary to add $40 \mathrm{mM}$ cycloheximide to the reaction mixture to prevent spore germination for each new reaction because cycloheximide became inactivated during turnover [21, $33]$. So the yeast spores were easily prepared and maintained for the sustainable biocatalysis.

More importantly, Saccharomyces cerevisiae spore has good resistance to extreme conditions. Much higher yields and optical purity by using the Spore E228S-GDH $_{\text {were }}$ obtained in ethyl acetate than free enzyme in aqueous phase. Those results are consistent with the TeSADH-catalyzed stereospecificial reduction reported by Phillips's group [34]. The enhanced yield in the enantioselective catalysis of linear ketones by the Spore ${ }_{\mathrm{E} 228 \mathrm{~S}-\mathrm{GDH}}$ in ethyl acetate than free enzyme in PBS solution may be due to the three reasons: the spore encapsulation supplies ADH enzymes with good resistance in organic solvents [16, 17]; the using of ethyl acetate can improve substrate solubility and accelerate the mass transportation; The different salvation of the enzyme active site by organic solvent makes the binding of substrate in the "wrong" orientation and favourable entropically. Filho et al. thought that the solvent functionality would be much more important rather than a single physicochemical parameter associated with the biocompatibility of organic solvents in ADH-catalyzed in biphasic reactions [35]. The enzyme Spore $_{\text {E228S-GDH }}$ exhibited different specificity towards ketones and ketoesters. The steric conformation

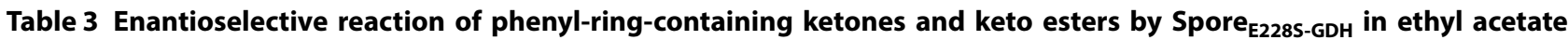
solution

\begin{tabular}{|c|c|c|c|c|c|c|}
\hline$n$ & R1 & $\mathrm{R} 2$ & Abs.Config. $^{a}$ & Yield (\%) & ee $(\%)$ & Time (h) \\
\hline 1 & $\mathrm{Ph}$ & $\mathrm{CH}_{3}$ & $(R)-1 \mathrm{~b}$ & $88(93)^{b}$ & $>99(>99)$ & $4.5(10)$ \\
\hline 2 & $\mathrm{Ph}-p-\mathrm{CH}_{3}$ & $\mathrm{CH}_{3}$ & $(R)-2 \mathrm{~b}$ & 79 (89) & $>99(>99)$ & $4(9)$ \\
\hline 3 & $\mathrm{Ph}-p-\mathrm{OCH}_{3}$ & $\mathrm{CH}_{3}$ & $(R)-3 \mathrm{~b}$ & $45(51)$ & $>99$ (>99) & $4(10)$ \\
\hline 4 & $\mathrm{Ph}-p-\mathrm{Br}$ & $\mathrm{CH}_{3}$ & $(R)-7 \mathrm{~b}$ & $81(90)$ & $>99(>99)$ & $4(10)$ \\
\hline 5 & $\mathrm{Ph}-p-\mathrm{Cl}$ & $\mathrm{CH}_{3}$ & $(R)-6 \mathrm{~b}$ & $85(93)$ & $>99(>99)$ & $4(10)$ \\
\hline 6 & $\mathrm{Ph}-\mathrm{O}-\mathrm{Cl}$ & $\mathrm{CH}_{3}$ & $(R)-4 \mathrm{~b}$ & $20(17)$ & $>99(>99)$ & $4(10)$ \\
\hline 7 & $\mathrm{Ph}-\mathrm{m}-\mathrm{Cl}$ & $\mathrm{CH}_{3}$ & $(R)-5 b$ & $25(28)$ & $>99(>99)$ & $4(10)$ \\
\hline 8 & $\mathrm{Ph}$ & $\mathrm{CH}_{2} \mathrm{OH}$ & $(S)-8 b$ & $14(13)$ & $>99$ (>99) & $4(8)$ \\
\hline 9 & $\mathrm{CH}_{3}\left(\mathrm{CH}_{2}\right)_{2}$ & $\mathrm{CH}_{3}$ & $(R)-9 b$ & $60(34)$ & $94(86)$ & $3(8)$ \\
\hline 10 & $\mathrm{CH}_{3}\left(\mathrm{CH}_{2}\right)_{3}$ & $\mathrm{CH}_{3}$ & $(R)-10 \mathrm{~b}$ & $56(27)$ & $91(73)$ & $3(8)$ \\
\hline 11 & $\mathrm{CH}_{3}\left(\mathrm{CH}_{2}\right)_{4}$ & $\mathrm{CH}_{3}$ & $(R)-11 b$ & $53(22)$ & $89(68)$ & $3(8)$ \\
\hline 12 & $\mathrm{CH}_{3}\left(\mathrm{CH}_{2}\right)_{5}$ & $\mathrm{CH}_{3}$ & $(R)-12 \mathrm{~b}$ & 43 (19) & $85(65)$ & $3(8)$ \\
\hline 13 & $\mathrm{CH}_{3} \mathrm{COO}$ & $\mathrm{O}-\mathrm{CH}_{3}$ & $(R)-13 b$ & $55(35)$ & $97(83)$ & $5(12)$ \\
\hline 14 & $\mathrm{CCl}_{3} \mathrm{COCH}_{2}$ & $\mathrm{O}-\mathrm{CH}_{2} \mathrm{CH}_{3}$ & $(R)-14 b$ & $52(26)$ & $90(77)$ & $5(12)$ \\
\hline 15 & $\mathrm{Ph}-\mathrm{CO}\left(\mathrm{CH}_{2}\right)_{2}$ & $\mathrm{O}-\mathrm{CH}_{3}$ & $(R)-15 b$ & $64(40)$ & $95(80)$ & $5(12)$ \\
\hline
\end{tabular}

Unless otherwise stated, all reactions were performed at $30^{\circ} \mathrm{C}$ in $1.7 \mathrm{~mL}$ PBS buffer $(100 \mathrm{mM}, \mathrm{pH} 7.4)$ and $0.3 \mathrm{~mL}$ ethyl acetate by using $0.1 \mathrm{~g}$ Spore $\mathrm{E}_{228 \mathrm{~S}-\mathrm{GDH}}$. The substrate concentration was $200 \mathrm{mM}$

a Absolute configuration. It was determined by comparing the retention time with that of standard samples

b The values in parentheses denote the enantioselective synthesis results of $60 \mathrm{mM}$ substrate to the corresponding chiral products with free enzyme in $2.0 \mathrm{~mL}$ PBS buffer $(100 \mathrm{mM}, \mathrm{pH} 7.4)$ at $30^{\circ} \mathrm{C}$ 
of the active site in the catalytic domain determines the substrate recognition, binding, and orientation in the enzyme [36]. The enzyme SCRII/E228S followed the antiPrelog rule for their behaviors in catalyzing asymmetric reduction of 2-HAP. SCRII poorly catalyzes the ortho substituted derivatives of acetophenone and 2-HAP with chloro or methyl at various positions of the phenyl ring, suggesting that the substitution at ortho position might have a steric effect on the hydrogen attack from electron donator NADPH to the carbonyl group and therefore significantly influence the biotransformation efficiency of the enzymes.

More significantly, the Spore E228S-GDH $_{\text {showed an }}$ extremely high long-term stability in repetitive freezing-thawing cycles; virtually no less in optical purity and a high yield of $(R)$-PE was detected after 20 weeks. When the Spore E228S-GDH was air-dried, it exhibited good yield for stereoselective synthesis of $(R)$-PE in PBS solution. These results further confirmed that the spore-encapsulation could protect catalytic functions of entrapped enzymes from extreme conditions [34]. However, the recombinant yeast SCRs was not reported to have the good resistance [28, 37].

We previously reported a coupled system containing C. parapsilosis E228S/SCRII and Bacillus sp. YX-1 GDH catalyzes the reduction of AP to $(R)-\mathrm{PE}$, but the higher substrate concentrations, shorter reaction time and sustainable reaction in organic solvents are preferred [3]. Liposomal encapsulation is reported as one of the best methods to protect enzymes against unsuitable external environments for stabilization of the enzyme structure and activity, but the low substrate permeability across the lipid membrane drastically limits the turnovers of encapsulated enzymes and thus has rather limited application [38-40]. Nasseau et al. improved the substrate permeability through the liposomes to a certain extent using a channel Omp F from the outer cell wall of $E$. coli, but they did not use it in enantioselective synthesis [41]. In 2007, Phillips's group successfully encapsulated Trp110Ala secondary alcohol dehydrogenase in xerogel for efficient reduction of hydrophobic ketones in organic solvents [34]. They reported a single-batch asymmetric reduction in water-immiscible organic solvents but rather the sustainable enantioselective synthesis using reusable catalysts would be of great significance [34]. The co-encapsulation of E228S/SCRII and GDH in S. cerevisiae AN120 osw $2 \Delta$ spore presented good resistance under extreme conditions and improved permeability of substrate/cofactor. During the interaction between enzymes and cofactors/the precursors, the active enzymes, E228S/SCRII and GDH were entrapped in loose-walled $S$. cerevisiae AN120 osw2 $\Delta$ spores, and the cofactor and precursors passed through the yeast spore walls smoothly [42, 43].
Moreover, the enzyme in spores showing good resistance and ability might be due to the enzyme in spores preventing it from protein denaturation by solvents.

The use of spore-microencapsulation of ADHs is of great advantage for several reasons beside the very economical and straightforward process operation (only the spore-encapsulated catalyst (as wet biomass), substrate, glucose, and a very small amount of cofactor were needed to start the reaction). First, it is much more stable than the free form, which makes it more suitable for variable reaction conditions, and more attractive to synthesis in organic solvents. Second, it makes the ADH enzymes with long-term reusability. Third, it makes enantioselective reaction proceed with easy product separation process since asymmetric reaction was performed in ethyl acetate.

\section{Conclusion}

In summary, we have developed a novel microencapsulation technique using yeast spore to coencapsulate C. parapsilosis E228S/SCRII and Bacillus sp. YX-1 GDH. The

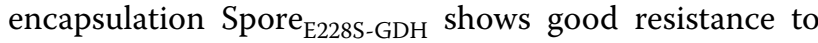
extreme conditions and excellent catalytic function with long-term and good recycling stabilities even with highly concentrated substrate. To the best of our knowledge, this work first described an efficient enantioselective synthesis in organic chemicals using spore coencapsulation of chiral-forming $\mathrm{ADH}$ and cofactor-recycling $\mathrm{ADH}$.

\section{Materials and methods \\ Microorganisms}

Candida parapsilosis Glu228Ser/(S)-carbonyl reductase (E228S/SCR II, EC1.1.1.148) and Bacillus sp. YX-1 glucose dehydrogenase (GDH, EC1.1.1.47) were obtained as described previously [3]. Escherichia coli JM109 was used as the host for gene cloning experiments. E. coli BL21/ E228S and E. coli/E228S-SD-AS-G was used as the DNA donor [3]. Saccharomyces cerevisiae AN120 osw2 $\Delta$ whose osw $2 \Delta$ gene was knocked out was used as the host for gene expression. E. coli was cultured at $37{ }^{\circ} \mathrm{C}$ in LuriaBertani (LB) medium, supplemented with kanamycin $\left(50 \mu \mathrm{g} \mathrm{mL}^{-1}\right)$ when necessary. S. cerevisiae was cultured at $30^{\circ} \mathrm{C}$ in yeast extract peptone dextrose (YPD) medium overnight, then $10 \mathrm{~mL}$ of the culture was shifted to $1 \mathrm{~L}$ YPAcetate (1\% yeast extract, $2 \%$ peptone, $2 \%$ potassium acetate) and grown $24 \mathrm{~h}$. The yeast cells were harvested by centrifugation and resuspended in $1 \mathrm{~L}$ of $2 \%$ potassium acetate medium, and cultured for $24 \mathrm{~h}$ to obtain spores.

\section{Chemicals}

Acetophenone (AP) (98\%), 4'-methylacetophenone (98\%), $4^{\prime}$-methoxyacetophenone (98\%), 4'-bromoacetophenone 
(98\%), 2'-chloroacetophenone (97\%), 3'-chloroacetophenone (98\%), 4'-chloroacetophenone (98\%), 2-hydroxyacetophenone (99\%), 2-pentanone (99\%), 2-hexanone (99\%), 2-heptanone (99\%), 2-octanone (99\%), methylacetoacetate (99\%), ethyl 4,4,4-trichloroacetoacetate (99\%), ethylbenzoylacetate (99\%), their corresponding chiral products, and NADPH were purchased from the SigmaAldrich Chemical Co. Inc (Shanghai, China) or obtained commercially. All other chemicals were of the highest grade that could be obtained commercially.

\section{Construction of coupled E228S/SCRII and GDH in S. cerevisiae AN120 osw2 $\Delta$}

Since the recombinant $E$. coli coexpressing Glu228Ser and GDH needed $12 \mathrm{~h}$ to complete asymmetric reaction, $S$. cerevisiae osw $2 \Delta$ was attempted to use for their expression to shorten reaction duration. E228S-SD-AS-G contains E228S/SCRII (SCRII Genbank ID: GQ411433) [3] and GDH genes (Genbank ID: NC014551.1) with a Shine-Dalgarno (SD) and aligned spacing (AS) sequence between them. The sequence of SD-AS is GAAGGA GATATACC with the supplemental amino acids of ArgArg-Asp-Ile. The $6 \times$ Histine was fused with $\mathrm{N}$ teminal of E228S and C terminal of GDH. The Pst I/Xho l fragments (E228S, GDH and E228S-SD-AS-G) were inserted into the Pst $\mathrm{I} /$ Xho 1 site of pRS424-TEF $F_{p r}$ and pRS424$T E F_{p r}$-GFP plasmid, respectively. The resulting plasmids pRS424-TEF $F_{p r}$-E228S, pRS424-TEF $F_{p r}$-GDH, pRS424$T E F_{p r}$-E228S-SD-AS-G pRS424-TEF $F_{p r}$-GFP-E228S, pRS424-TEF $F_{p r}$-GFP-GDH and pRS424-TEF $F_{p r}$-GFPE228S -SD-AS-G were confirmed by DNA sequencing.

The six recombinant plasmids were chemically introduced into S. cerevisiae AN120 osw $2 \Delta$ competent cells respectively. The positive strains $S$. cerevisiae osw $2 \Delta /$ E228S, S. cerevisiae osw $2 \Delta / \mathrm{GDH}, S$. cerevisiae osw $2 \Delta /$ E228S-SD-AS-G, S. cerevisiae osw2 $/$ GFP-E228S, $S$. cerevisiae osw2 $2 \Delta / \mathrm{GFP}-\mathrm{GDH}$ and $S$. cerevisiae osw $2 \Delta /$ GFP-E228S-SD-AS-G were obtained by SD-Trp screening [18].

\section{Obtaining spore-microencapsulated ADHs}

The spore-encapsulation was prepared using the method as described by Kloimwieder and Winston [44] with some minor modification. The above six recombinant $S$. cerevisiae osw $2 \Delta$ were grown in YPD liquid media with appropriate supplemental amino acids overnight, and then shifted to the medium containing $1 \%$ yeast extract, $2 \%$ peptone and $2 \%$ potassium acetate for $24 \mathrm{~h}$. The cells were harvested by centrifugation, washed with $\mathrm{H}_{2} \mathrm{O}$, resuspended in $30 \mathrm{~mL}$ of $2 \%$ potassium acetate medium, and cultured for $24 \mathrm{~h}$, when sporulation efficiency (the number ratio of spores and cells) of $S$. cerevisiae osw $2 \Delta$ was over $90 \%$ by microscopy [22]. The spores resuspended in $1 \mathrm{~mL}$ spheroplast buffer $(\mathrm{pH} 7.0)$ containing $50 \mathrm{mM}$ potassium phosphate, $1.4 \mathrm{M}$ sorbitol, $40 \mathrm{mM}$ $\beta$-mercaptoethanol, and mixed with $50 \mu \mathrm{L} \beta$-glucanase solution $(1 \mathrm{mg} \beta$-glucanase was dissolved in $500 \mu \mathrm{L}$ of $50 \%$ glycerol). After $1 \mathrm{~h}$ of incubation at $37{ }^{\circ} \mathrm{C}$, spores were washed twice with spheroplast buffer, and then resuspended in spheroplast buffer and sonicated to disrupt the ascal membrane [44]. The resulting pellet were washed three times with $0.5 \%$ Triton- $\mathrm{X}$ and resuspended in $1 \mathrm{~mL}$ of $0.5 \%$ Triton-X and layered on top of Percoll (Sigma-Aldrich, Shanghai, China) gradients $(50-80 \%$ Percoll, 10\% 2.5 M sucrose and 0.5\% Triton-X). After centrifugation at $15,000 \times g$ at $4{ }^{\circ} \mathrm{C}$ for $1 \mathrm{~h}$, the vegetative cells and debris was removed. The purified spore encapsulation containing E228S/SCRII and GDH were obtained and stored at $-20^{\circ} \mathrm{C}$.

\section{Microscopy}

To indentify the spores keeping in dormancy, the microscope images of spores were observed by using Nikon Eclipse Ti-E inverted microscope equipped with DS-Ri1 camera and NIS-Element AR software (Nikon, Tokyo, Japan). Samples were drop-cast from sodium phosphate buffer solution onto copper coated TEM grids. Transmission electron microscopy was carried out on a JEOL $2000 \mathrm{EX}$ operating at $200 \mathrm{keV}$. The spore and cell numbers were observed and counted in 20 visual fields by microscopy. The number ratio between spore and cells was calculated. The average value of ratio from visual fields was defined as sporulation efficiency [18].

\section{Western blotting}

Western blot analysis of spores was performed to indentify the ADH expression in S. cerevisiae AN120 osw2 $\Delta$ spores. Spores were washed with water, suspended in $500 \mu \mathrm{L}$ of $8 \mathrm{M}$ urea, and lysed by high pressure for $1 \mathrm{~h}$ on ice. The ADH specificity in the total proteins was probed with His $\times$ tag monoclonal antibody (Ab1, Novagen), followed by rabbit anti-mouse IgG conjugated to horseradish peroxidase (Ab2, BioLab) against $\mathrm{Ab} 1$ and visualized by Enhanced Chemiluminescence system (Amersham) for $15 \mathrm{~min}$ according to the instructions.

\section{Enzyme assay and kinetics measurement}

The enzymatic activities of E228S/SCRII for the reduction of AP were measured at $35{ }^{\circ} \mathrm{C}$ by recording the rate of change in the $\mathrm{NAD}(\mathrm{P}) \mathrm{H}$ absorbance at $340 \mathrm{~nm}$ [45]. The assay mixture for the GDH activity contained $100 \mathrm{mM}$ Tris- $\mathrm{HCl}$ (pH 8.0), $100 \mathrm{mM}$ glucose, and $2 \mathrm{mM}$ $\mathrm{NADP}^{+}$, and the reactions at $30{ }^{\circ} \mathrm{C}$. One unit of activity is defined as the amount of enzyme catalyzing the oxidation 
of $1 \mu \mathrm{mol}$ NADPH or the reduction of $1 \mu \mathrm{mol} \operatorname{NAD}(\mathrm{P})^{+}$ under the measurement condition, respectively.

The kinetic parameters of protein were measured and calculated using a Beckman DU-7500 spectrophotometer with a Multicomponent/SCA/Kinetics Plus software package and a thermostated circulating water bath. Substrate ( 0.5 to $20 \mathrm{mM})$, enzyme $\left(\sim 30 \mu \mathrm{M}, 1 \mathrm{mg} \mathrm{mL}^{-1}\right)$, and cofactor NADPH (5 mM) in $100 \mathrm{mM}$ potassium phosphate buffer $(\mathrm{pH}$ 6.0) were used for a series of assays. Each value was calculated depending on three independent measurements and all standard errors of fits were not more than $5 \%$. Kinetic parameters were derived from Michaelis-Menten plots and Lineweaver-Burk.

\section{Biotransformation and analytical methods}

The asymmetric biotransformation by spore-microencapsulation were carried out in a $10 \mathrm{~mL}$ or $500 \mathrm{~mL}$ flask equipped with a magnetic stirrer as described previously [3], with minor modifications. The reaction mixture consisted of $0.1 \mathrm{M}$ potassium phosphate buffer ( $\mathrm{pH} 6.5)$, 8-25 $\mathrm{g} \mathrm{L}^{-1}$ AP, $10-30 \mathrm{~g} \mathrm{~L}^{-1}$ glucose, $0.02 \mathrm{mM} \mathrm{NADPH}$, and $0.1 \mathrm{~g}$ yeast spores at $35^{\circ} \mathrm{C}$. Cycloheximide of $40 \mathrm{mM}$ was added in the reaction mixture to prevent spore germination [33]. The reaction time was from 1 to $10 \mathrm{~h}$. At the end of the reaction, the products were extracted with $100 \%$ ethyl acetate which was twofold volume of reaction mixture, and the organic layer was used for analysis. The optical purity and yield of the product were determined using HPLC or GS on a Chiralcel OB-H column (Daicel Chemical Ind. Ltd., Japan). The calculation equations are as follows: the optical purity of $(R)$-enantiomer $=\left[\left(\mathrm{S}_{\mathrm{R}}-\mathrm{S}_{\mathrm{S}}\right) /\left(\mathrm{S}_{\mathrm{S}}+\mathrm{S}_{\mathrm{R}}\right)\right] \times 100 \%$, and the yield of $(R)$-enantiomer $=(\mathrm{CR} / 138) /(\mathrm{CH} / 136) . \mathrm{S}_{\mathrm{R}}$, the peak area of $(R)$-enantiomer; $\mathrm{S}_{\mathrm{S}}$, the peak area of $(S)$-enantiomer; $C R$, peak area corresponding to concentration of $(R)$ enantiomer after reaction; $\mathrm{CH}$, peak area corresponding to concentration of substrate before reaction.

\section{Stability of spore encapsulation}

For thermal inactivation, the spore-microencapsula-

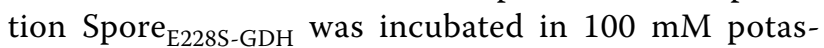
sium phosphate $(\mathrm{pH} 6.5)$ at $20-80{ }^{\circ} \mathrm{C}$ for $1 \mathrm{~h}$ [32]. To determine $\mathrm{pH}$ dependence, the entrapped enzymes was incubated between $\mathrm{pH} 4.0$ and 10.0 at $4{ }^{\circ} \mathrm{C}$ for $5 \mathrm{~h}$. To determine organic resistance, all reaction were performed as described above except with the addition of $15 \%$ organic solvents.

For air-drying treatment, the spore microencapsulation was kept in incubator at $16{ }^{\circ} \mathrm{C}$ or $30{ }^{\circ} \mathrm{C}$ for $24 \mathrm{~h}$. For repetitive freezing-thawing treatment, the spore microencapsulation was frozen at $-20{ }^{\circ} \mathrm{C}$ and was thawed at room temperature. The freezing-thawing process was repeated at least once a day. Some of spore microencapsulation was used for reaction, and the rest was taken back to refrigerator at $-20{ }^{\circ} \mathrm{C}$. The experiments lasted for 20 weeks.

\section{Usability of spore microencapsulation}

After each enantioselective synthesis was finished, the spore microencapsulation was washed with $\mathrm{H}_{2} \mathrm{O}$. After centrifugation, the supernatant was removed and the washed spores were used for next reaction. Cycloheximide $(40 \mathrm{mM})$ was added to the reaction system to prevent spore germination for each new reaction (Additional file 1).

\section{Additional file}

Additional file 1: Figure S1. Microscope images of enzyme-encapsulated spores cultured with YPD and reaction mixture. Figure S2. Optimal temperature and $\mathrm{pH}$ value on enantioselective synthesis of (R)-PE by

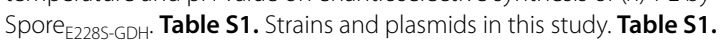
Strains, plasmids and primers in this study. Table S2. Analytical methods of corresponding chiral products.

\section{Abbreviations}

AP: acetophenone; E228S: Glu228Ser; ee: enantiomeric excess; Free $E_{E 2285}$ : free

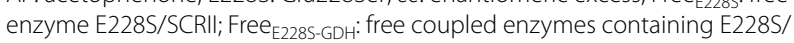
SCRII and GDH; GDH: glucose dehydrogenase; $(R)-P E D:(R)$-phenylethanol;

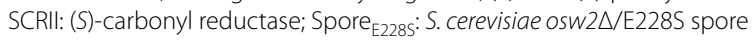

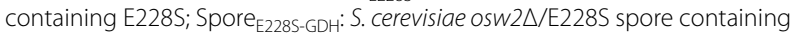
E228S and GDH.

\section{Acknowledgements}

Not applicable.

\section{Authors' contributions}

JXR Led the design and performance of the experiments, analysis of data and writing of the paper. HBL, XDG and HN participated in experimental design and analysis. RZZ, and YX participated in editing the paper. All authors read and approved the final manuscript.

\section{Funding}

This work was supported by the National Science Foundation of China (31370100), the Program for Advanced Talents within Six Industries of Jiangsu Province (2015-SWYY-010), the National First-class Discipline Program of Light Industry Technology and Engineering (LITE2018-12), and the Program of Introducing Talents of Discipline to Universities (111-2-06).

\section{Availability of data and materials}

The datasets of supporting the conclusions in this article are included in the manuscript and additional file.

\section{Ethics approval and consent to participate}

Not applicable.

\section{Consent for publication \\ Not applicable.}

\section{Competing interests}

The authors declare that they have no competing interests. 


\section{Author details}

${ }^{1}$ College of Science of China Pharmaceutical University, Nanjing 211198, People's Republic of China. ${ }^{2}$ Key Laboratory of Industrial Biotechnology of Ministry of Education \& School of Biotechnology, Jiangnan University, Wuxi 214122, People's Republic of China. ${ }^{3}$ Key Laboratory of Carbohydrate Chemistry and Biotechnology, Ministry of Education, School of Biotechnology, Jiangnan University, Wuxi, China. ${ }^{4}$ Present Address: School of Biotechnology, Jiangnan University, 1800 Lihu Avenue, Wuxi 214122, People's Republic of China.

Received: 3 January 2019 Accepted: 8 May 2019

Published online: 20 May 2019

\section{References}

1. Gröger H, Hummel W, Buchholz S, Drauz K, Nguyen TV, Rollmann C, Hüsken H, Abokitse K. Practical asymmetric enzymatic reduction through discovery of a dehydrogenase-compatible biphasic reaction media. Org Lett. 2003;5:173-6.

2. Wang $S, X u Y$, Zhang RZ, Zhang BT, Xiao R. Improvement of (R)-carbonyl reductase-mediated biosynthesis of $(R)$-1-phenyl-1,2-ethanediol by a novel dual-cosubstrate-coupled system for $\mathrm{NADH}$ recycling. Process Biochem. 2012;47:1060-5.

3. Zhang RZ, Zhang BT, Xu Y, Li YH, Li M, Liang HB, Xiao R. Efficicent (R)phenylethanol production with enantioselectivity-alerted (S)-carbonyl reductase II and NADPH regeneration. PLoS ONE. 2013;8:e83586.

4. Cao L, Langen LV, Sheldon RA. Immobilised enzymes: carrier-bound or carrier-free? Curr Opin Biotechnol. 2003;14:387-94.

5. Gervais TR, Carta G, Gainer JL. Asymmetric synthesis with immobilized yeast in organic solvents: equilibrium conversion and effect of reactant partitioning on whole cell biocatalysis. Biotechnol Prog. 2010;19:389-95.

6. Schroer K, Zelic B, Oldiges M, Lütz S. Metabolomics for biotransformations: intracellular redox cofactor analysis and enzyme kinetics offer insight into whole cell processes. Biotechnol Bioeng. 2009;104:251-60.

7. Wandrey C. Biochemical reaction engineering for redox reactions. Chem Rev. 2004;4:254-65.

8. Liu W, Zhang S, Wang P. Nanoparticle-supported muti-enzyme biocatalysis with in situ cofactor regeneration. J Biotechnol. 2009;139:102-7.

9. El-Zahab B, Donnelly D, Wang P. Particle-tethered NADH for production of methanol from $\mathrm{CO}(2)$ catalyzed by coimmobilized enzymes. Biotechnol Bioeng. 2008;99:508-14.

10. El-Zahab B, Jia H, Wang P. Enabling multienzyme biocatalysis using nanoporous materials. Biotechnol Bioeng. 2004;87:178-83.

11. Garg B, Bish T, Ling Y-C. Graphene-based nanomaterials as efficient peroxidase mimetic catalysts for biosensing applications: an overview. Molecules. 2015:20:14155-90.

12. $\mathrm{Hu} \mathrm{Q}$, Kattic PS, Gu Z. Enzyme-responsive nanomaterials for controlled drug delivery. Nanoscale. 2014;6:12273-86.

13. Mazurenko I, Monsalve K, Rouhana J, Parent P, Laffon C, Goff AL, Szunerits S, Boukherroub R, Giudici-Orticoni M-T, Mano N, Lojou E. How the intricate interactions between carbon nanotubes and two bilirubin oxidases control direct and mediated $\mathrm{O}_{2}$ reduction. ACS Appl Mater Interfaces. 2016:8:23074-85.

14. Liu W, Wang P. Cofactor regeneration for sustainable enzymatic biosynthesis. Biotechnol Adv. 2007;25:369-84.

15. Neiman A. Ascospore formation in the yeast Saccharomyces cerevisiae. Microbiol Mol Biol Rev. 2005;69:565-84.

16. Suda Y, Rodriguez R, Coluccio A, Neiman A. A screen for spore wall permeability mutants identifies a secreted protease required for proper spore wall assembly. PLoS ONE. 2009;4:e7184.

17. Coluccio A, Bogengruber E, Conrad MN, Dresser ME, Briza P, Neiman AM. Morphogenetic pathway of spore wall assembly in Saccharomyces cerevisiae. Eukaryot Cell. 2004;3:1464-75.

18. Shi L, Li Z, Tachikawa H, Gao X, Nakanishi H. Microencapsulation of enzymes using yeast spores. Appl Environ Microbiol. 2014;80:4502-10.

19. Neiman A. Sporulation in the budding yeast Saccharomyces cerevisiae. Genetics. 2011;189:737-65.

20. Chen $H$, Bjerknes M, Kumar R, Jay E. Determination of the optimal aligned spacing between the Shine-Dalgarno sequence and the translation initiation codon of Escherichia coli mRNAs. Nucleic Acids Res. 1994;22:4953-7.

21. Tufvesson P, Lima-Ramos J, Nordblad M, Woodley JM. Guidelines and cost analysis for catalyst production in biocatalytic processes. Org Process Res Dev. 2011;15:266-74.

22. Gerke JP, Chen CTL, Cohen BA. Natural isolates of Saccharomyces cerevisiae display complex genetic variation in sporulation efficiency. Genetics. 2006;74:985-97.

23. $M u X Q, X u Y$, Yang $M$, Sun $Z H$. Steady-state kinetics of the oxidation of (S)-1-phenyl-1,2-ethanediol catalyzed by alcohol dehydrogenase from Candida parapsilosis CCTCC M203011. J Mol Catal B. 2006;43:23-8.

24. García-Urdiales E, Alfonso I, Gotor V. Update 1 of: enantioselective enzymatic desymmetrizations in organic synthesis. Chem Rev. 2011;111:110-80.

25. Huang Y, Liu N, Wu XR, Chen YJ. Dehydrogenases/reductases for the synthesis of chiral pharmaceutical intermediates. Curr Org Chem. 2010;14:1447-60.

26. Kroutil W, Mang H, Edegger K, Faber K. Recent advances in the biocatalytic reduction of ketones and oxidation of sec-alcohols. Curr Opin Chem Biol. 2004;8:120-6.

27. Schmid A, Dordick JS, Hauer B, Kiener A, Wubbolts M, Witholt B. Industrial biocatalysis today and tomorrow. Nature. 2001;409:258-68.

28. Zhang R, Xu Y, Wang S, Zhang B, Geng Y. Expression and subcellular location of $(R)$ - and (S)-specific carbonyl reductases from Candida parapsilosis in Saccharomyces cerevisia. Acta Microbiol Sinica. 2011;51:789-95.

29. Yang X, Li Z, Liu B, Klein-Hofmann A, Tian G, Feng Y, Ding Y, Su D, Xiao F. "Fish-in-net" encapsulation of enzymes in macroporous cages as stable, reusable, and active heterogeneous biocatalysts. Adv Mater. 2006;18:410-4.

30. Kang S, Douglas T. Some enzymes just need a space of their own. Science. 2010:327:42-3.

31. Stampfer W, Kosjek B, Moitzi C, Kroutil W, Faber K. For selected contributions on substrate-coupled cofactor regeneration with 2-propanol in the asymmetric enzymatic reduction of ketones. Angew Chem. 2002:114:1056-9.

32. Gröger H, Chamouleau F, Orologas N, Rollmann C, Drauz K, Hummel W, Weckbecker A, May O. Enantioselective reduction of ketones with "designer cells" at high substrate concentrations: highly efficient access to functionalized optically active alcohols. Angew Chem Int Ed. 2006:45:5677-81.

33. Herman $P$, Rine J. Yeast spore germination: a requirement for Ras protein activity during re-entry into the cell cycle. EMBO J. 1997;16:6171-81.

34. Musa MM, Ziegelmann-Fjeld KI, Vieille C, Zeikus JG, Phillips RS. Xerogelencapsulated W110A secondary alcohol dehydrogenase from Thermoanaerobacter ethanolicus performs asymmetric reduction of hydrophobic ketones in organic solvents. Angew Chem Int Ed. 2010;119(17):3151-4.

35. Filho MV, Stillger T, Müller M, Liese A, Wandrey C. Choice of solvents for biphasic enzymatic reactions? Angew Chem Int Ed. 2003;42:2993-6.

36. Zhu D, Mukherjee C, Rozzell JD, Kambourakis S, Hua L. A recombinant ketoreductase tool-box. Assessing the substrate selectivity and stereoselectivity toward the reduction of $\beta$-ketoesters. Tetrahedron. 2006;62:901-5

37. Zhang R, Xu Y, Xiao R, Zhang B, Wang L. Optimized expression of (S)-carbonyl reductase in Pichia pastoris for efficient production of (S)1-phenyl-1, 2-ethanediol. J Basic Microbiol. 2014;54:873-9.

38. Yoshimoto M, Sato M, Yoshimoto N, Nakao K. Liposomal encapsulation of yeast alcohol dehydrogenase with cofactor for stabilization of the enzyme structure and activity. Biotechnol Prog. 2008;24:576-82.

39. Yoshimoto M. Stabilization of enzymes through encapsulation in liposomes. Methods Mol Biol. 2011;679:9-18.

40. Chandrawati R, Odermatt PD, Chong S-F, Price AD, Städler B, Caruso F. Triggered cargo release by encapsulated enzymatic catalysis in capsosomes. Nano Lett. 2011;11:4958-63.

41. Nasseau M, Boublik Y, Meier W, Winterhalter M, Fournier D. Substrate-permeable encapsulation of enzymes maintains effective activity, stabilizes against denaturation, and protects against proteolytic degradation. Biotechnol Bioeng. 2001;75:615-8.

42. Urabe Y, Shiomi T, Itoh T, Kawai A, Tsunoda T, Mizukami F, Sakaguchi K. Encapsulation of hemoglobin in mesoporous silica (FSM)-enhanced 
thermal stability and resistance to denaturants. ChemBioChem. 2007:8:668.

43. Pandya PH, Jasra RV, Newalkar BL, Bhatt PN. Studies on the activity and stability of immobilized a-amylase in ordered mesoporous silicas. Microporous Mesoporous Mater. 2005;77:67-77.

44. Kloimwieder A, Winston F. A screen for germination mutants in Saccharomyces cerevisiae. G3. 2011;1:143-9.

45. Zhang RZ, Geng YW, Xu Y, Zhang WC, Wang SS, Xiao R. Carbonyl reductase SCRII from Candida parapsilosis catalyzes anti-Prelog reaction to (S)-1-phenyl-1,2-ethanediol with absolute stereochemical selectivity. Bioresour Technol. 2011;102:483-9.

\section{Publisher's Note}

Springer Nature remains neutral with regard to jurisdictional claims in published maps and institutional affiliations. 